\title{
Correspondence: Analytical flaws in a continental-scale forest soil microbial diversity study
}

\author{
Leho Tedersoo ${ }^{1}$
}

Nature Communications 8:15572 doi: 10.1038/ncomms15572 (2017); Published 6 Jun 2017

Zhou et al. ${ }^{1}$ recently addressed continental-scale biogeographic patterns of soil microorganisms. The authors suggested that the mean annual temperature rather than other environmental predictors drive the latitudinal gradient of diversity in soil bacteria and fungi sampled from six permanent study areas across North America. Here I argue that their approach is flawed because of pseudoreplicated design, incorrect choice of statistical tools and overoptimistic interpretation.

From each of the six sites, the authors collected 21 composite soil cores (located 1-400 $\mathrm{m}$ apart) that were treated as independent sampling units to infer continental-scale patterns. The authors then used simple regression analyses to address the differences among samples instead of nesting samples within sites or using sites as categorical predictors, thus overestimating the residual degrees of freedom by 31 -fold. Further, the authors calculated Chaol minimum richness estimates for each site as proxies of diversity to test the response of richness to environmental variables. However, the minimum richness estimates are based on relative abundance of the rare taxa ${ }^{2}$. Most of this 'rare biosphere' in metabarcoding studies (such as Zhou et al. ${ }^{1}$ ) may represent unfiltered analytical artefacts ${ }^{3,4}$ and magnify the differences in richness among taxon-poor and taxon-rich sites ${ }^{4}$. After integrating richness into Chaol estimates, the authors conducted simple and multiple regression analyses for many explanatory variables, determining that inversely transformed temperature represents the best linear predictor for microbial richness. While this holds true for the current very limited sampling on a continental scale, inclusion of soils from broader range of $\mathrm{pH}$ and precipitation are likely to alter this pattern.

Previous research has indicated that on global and continental scales, soil $\mathrm{pH}$ and precipitation constitute the strongest predictors of richness and composition of terrestrial microorganisms ${ }^{5-10}$. Several of these studies have also identified temperature as one of the key predictors. Furthermore, two global studies previously reported that temperature is the strongest predictor of bacterial $^{11}$ and fungal ${ }^{12}$ richness. Zhou et al. ${ }^{1}$ neglected to cite these studies, and thus over-emphasized the novelty of connecting temperature to the latitudinal gradient of diversity in microbes.
It has been well established that true replication is a cornerstone of experimental design in ecology ${ }^{13}$ and microbiology ${ }^{4,14}$ to secure correct data analysis and interpretation. Proper replication as well as spatially independent and representative samples is required to infer both small-scale and large-scale biogeographic patterns and processes. Samples that serve as good replicates on a fine scale may be, however, unsuited for this purpose over large geographic scales without introducing nested design or accounting for spatial autocorrelation. Therefore, I urge researchers to carefully consider replication on a relevant geographic scale in the discipline of biogeography.

\section{References}

1. Zhou, J. et al. Temperature mediates continental-scale diversity of microbes in forest soils. Nat. Commun. 7, 12083 (2016).

2. Gotelli, N. \& Chao, A. in Encyclopedia of Biodiversity (ed. Levin, S. A.) 195-210 (Elsevier, 2013).

3. Lynch, M. D. \& Neufeld, J. D. Ecology and exploration of the rare biosphere. Nat. Rev. Microbiol. 13, 217-229 (2015).

4. Bálint, M. et al. Millions of reads, thousands of taxa: microbial community structure and associations analyzed via marker genes. FEMS Microbiol. Rev. 40 , 686-700 (2016).

5. Bates, S. T. et al. Global biogeography of highly diverse protistan communities in soil. ISME J. 7, 652-659 (2013).

6. Lauber, C., Hamady, M., Knight, R. \& Fierer, N. Pyrosequencing-based assessment of soil $\mathrm{pH}$ as a predictor of soil bacterial community structure at the continental scale. Appl. Environ. Microbiol. 75, 5111-5120 (2009).

7. Maestre, F. T. et al. Increasing aridity reduces soil microbial diversity and abundance in global drylands. Proc. Natl Acad. Sci. USA 112, 15684-15689 (2015).

8. Põlme, S. et al. Biogeography of ectomycorrhizal fungi associated with alders (Alnus spp.) in relation to biotic and abiotic variables at the global scale. New Phytol. 198, 1239-1249 (2013).

9. Talbot, J. M. et al. Endemism and functional convergence across the North American mycobiome. Proc. Natl Acad. Sci. USA 111, 6341-6346 (2014).

10. Tedersoo, L. et al. Global diversity and geography of soil fungi. Science 346, 1078 (2014).

11. Prober, S. M. Plant diversity predicts beta but not alpha diversity of soil microbes across grasslands worldwide. Ecol. Lett. 18, 85-95 (2015).

12. Tedersoo, L. et al. Towards global patterns in the diversity and community structure of ectomycorrhizal fungi. Mol. Ecol. 21, 4160-4170 (2012).

13. Hurlbert, S. H. Pseudoreplication and the design of ecological field experiments. Ecol. Monogr. 54, 187-211 (1984).

14. Prosser, J. I. Replicate or lie. Environ. Microbiol. 12, 1806-1810 (2010).

\footnotetext{
${ }^{1}$ Natural History Museum, University of Tartu, 14a Ravila, 50411 Tartu, Estonia. Correspondence and requests for materials should be addressed to L.T. (email: leho.tedersoo@ut.ee).
} 


\section{Author contributions}

L.T. wrote the correspondence.

\section{Additional information}

Competing interests: The authors declare no competing financial interests.

Reprints and permission information is available online at http://npg.nature.com/ reprintsandpermissions/

How to cite this article: Tedersoo, L. Analytical flaws in a continental-scale forest soil microbial diversity study. Nat. Commun. 8, 15572 doi: 10.1038/ncomms15572 (2017).
Publisher's note: Springer Nature remains neutral with regard to jurisdictional claims in published maps and institutional affiliations.

(c) (i) This work is licensed under a Creative Commons Attribution 4.0 International License. The images or other third party material in this article are included in the article's Creative Commons license, unless indicated otherwise in the credit line; if the material is not included under the Creative Commons license, users will need to obtain permission from the license holder to reproduce the material. To view a copy of this license, visit http://creativecommons.org/licenses/by/4.0/

(C) The Author(s) 2017 